\title{
AN ANALYSIS OF ID AND EGO NOVEL "A TALE OF TWO CITIES” BY CHARLES DICKENS
}

\author{
Romanna' Gaguk Rudianto \\ romanna8989@gmail.com,gagukrudianto@gmail.com \\ Student of English Department, Lecturer of English Department \\ Putera Batam University
}

\begin{abstract}
This study aims to describe the id and ego of the characters in the novel A Tale of Two Cities by Charles Dickens using the approach of psychological approach. This type of research is a qualitative descriptive study and the data obtained from this study produce a psychological analysis in the Charles Dickens novel entitled "A Tale of Two Cities". There are two psychiatric structures that are described in this study, namely the id and the ego using the theory of Sigmund Freud.
\end{abstract}

Keywords: Psychological Approach, Novel, A Tale of Two Cities

\section{INTRODUCTION}

Literature is the activity of creative which is a tool to express and convey feelings of humans or also message. Humans are creatures of social, by because of it, is very much the story and inspiration who want to express that so that comes the work of literature such as novels, poetry, and others are where it all serves as a tool to express a message. Because literature develops very rapidly, then held literature as a field of science to assess and criticize works of literature. Literary works are general and at the same time special. The study of literature is a branch of scientific knowledge that is evolving constantly for work of literature even today increasingly growing. Not only examines the works of literature earlier, but it also examines the works of literature were created in the past now.

With the development of the science of literature, it is not only the element that is in the works of literature alone is studied, but factor outside as well. The factor of a factor outside of a work of literature is the sociology of literature, psychology literature, and anthropology literature. Sociology of literature is the study of science that the human being in society, the process of social and also about the institution. While the anthropology literature is the science that the reviewer literature 
based on study intercultural that where related to origins of literature.

In this study, researcher are interested in studying the novel a tale of two cities by Charles Dickens, which uses the approach of the psychological approach theory from Sigmund Freud by analyzing the psychological structure contained in the psychiatric novel characters, namely id, and ego. In Lapsley \& Stey (2011) Freud stated that the "lower portion" of the ego extends throughout the id, and it is by means of the id that repressed material communicates with (presses "up" against the resistances of) the ego. It means that the ego neutralizes the desire of the id to achieve its satisfaction. ID and ego are separate but interacting with physics structure and the key to a healthy personality is the balancing between them.

In Rennison (2001) Freud stated that the oldest and most primitive part of the mind is the id. ID (Internal Drive) is the mind of all people who are brought from birth. In Angggoro (2010) Oishi and Koo expressed that happiness is a latent construct that is generally indicated to be the best through the level of satisfaction. That's why id is a person's impulse to satisfy his selfish desires to achieve the pleasure principle.

According to Navaneedhan (2012) ego is that part of the ID which has been modified by the direct influence of the external world. When the id has ambitions to satisfy its desires, then the ego limits it. The ego tolerates all id wishes and removed desires from fantasy. So the main task of the ego is to balance between id and consideration.

\section{REVIEW OF THE RELATED LITERATURE}

The increasing influence of the psychological approach on the sociology of suicide has become evident. For Shneidman (2004:122) suicide is the permanent solution to a temporary problem. Suicide is a multidimensional distress of which the main component is always psychological. Suicidal people always suffer from an unbearable psychological pain and from a cognitive constriction. Suicide becomes the only solution for their problems.

Psychological approach is psychology that plays an important role in a literary work by examining from the psychiatric angle of the literary work both from the element of the character, author, and readers. The inner conflict contained in a literary work will be revealed if what is studied is from author's elements. In other words, the relationship of literary work with psychology is very close to creating a new science called psychological approach.

Id, is the basic function possessed by humans, which are selfish, not competitive, and the goal of getting as much pleasure (without conditions or pleasure principles) without caring or facilitating morality. This id is in the human subconscious. 
The ego, is the second function of human beings, which is challenging and executive (who takes action). Acceptable goals seek challenging ones to fulfill the id (the principle of reality). Ego is in the human conscious world.

\section{RESEARCH METHOD}

Following the title and purpose of the study, this type of research is qualitative research, because qualitative research according to Wibowo (2013:38) qualitative research is research used to find out and analyze what is not seen or in other words, qualitative research looks at the content of the communication that is implied. By using qualitative research researcher can see what is behind a literary work in the form of words and language.

The data in this research are in the form of psychological approach from Sigmund Freud's theory namely id and ego. The data source in this study comes from the novel A Tale of Two Cities by Charles Dickens with 537 pages and 1857 published year.

The several data collection techniques used by researcher are document studies in which document studies are conducted by reviewing documents related to the research topic. The method used by researcher, namely: looking for references about the psychology of literature to be studied, read the Tale of Two Cities novel repeatedly then mark the results found in the form of id and ego, the results found in the novel are copied to the laptop.
The data found during the data collection process is then analyzed using Sigmund Freud's theory with the following steps:

1. ID (Internal Drive)

2. Ego

\section{FINDINGS AND DISCUSSION}

Based on this research, the researcher uses a psychological approach to analyze the personality of a character in the novel A Tale of Two Cities by Charles Dickens. The theory used by researcher is Sigmund Freud's theory which says that 3 personality structures are carried out to determine a person's psychology, namely the id, the ego, and the superego. But in this study, researcher only focused on the id and the ego.

Here are some of the findings of researcher regarding the id and ego in the novel A Tale of Two Cities:

\section{Id}

Because the Evremonde family committed sin and oppression, each of his descendants must be held responsible and put to death.

'An innocent man was to die for the sins of his forefathers; she saw, not him, but for them. It was nothing to her, that his wife was to be made a widow and his daughter an orphan; that was insufficient punishment because they were her natural enemies and her prey, and as such had 
no right to live' Dickens

(1859:516)

Madame Defarge went to see Lucie get Lucie punished as well. Madame Defarge's behavior was influenced by her revenge in the past.

Gaspard decided to kill the Marquis at night when he fell into a deep sleep from being drunk on his bed because of revenge.

'It lay back on the pillow of Monsieur the Marquis. It was like a fine mask, suddenly startled, made angry, and petrified. Driven home into the heart of the stone figure attached to it was a knife. Round its hilt was a frill of paper, on which was scrawled: 'Drive him fast to his tomb. This, from Jacques.' Dickens (1859:182)

The murder of the Marquis was based on Gaspar's revenge against him. Gaspard's son died by the Marquis and was mistreated by him. With this murder, it means that Gaspard can't control his emotions and he prefers to use his ID sense.

\section{Ego}

Darney was willing to leave all of his family's wealth and move to London and become a tutor because he felt what his family had been doing was wrong, and he disagreed with that.

'We have so asserted our station, both in the old-time and in the modern time also,' said the nephew, gloomily, 'that I believe our name to be more detested than any name in France.' Dickens (1859:173)

Means Darney is the type of person who is not crazy about wealth and he can be put into the type of ego.

Everyone who has the right to determine the true or false of Darney in court chose to free Darney because he is the son in law of Dr. Manette, a physician in the past.

'At every vote (the Jurymen voted aloud and individually), the populace set up a shout of applause. All the voices were in the prisoner's favour, and the President declared him free' Dickens (1859:407)

People ignored Darney's mistake for remembering Dr. Manette as a physician to them and prefers to free Darney from his fault.

\section{CONCLUSION AND SUGGESTION}

\section{A. Conclusion}

This study aims to identify the id and ego forms of the characters in the novel A Tale of Two Cities which was one of the works of Charles Dickens in 1859. The id is the side of the soul that encourages humans to satisfy their desires immediately, while the ego is the side of the soul that controls id.

To get the results of the study, researcher used document study techniques in which the researcher read the entire contents of the novel and 
looked for research studies related to the id and the ego. In this study, researcher used a psychological approach theory approach from Sigmund Freud. From the results of the study, the researcher concluded that a person's psychology or psychology was influenced by the id and the ego.

\section{B. Suggestion}

Although researcher want perfection in the preparation of this study, there are still many shortcomings that researcher need to improve again. This is due to the lack of knowledge of researcher. Therefore constructive criticism and suggestions from readers are expected to be an evaluation material for further research.

\section{REFERENCES}

Angggoro, W. J. (2010). Konstruksi dan Identifikasi Properti Psikometris Instrumen Pengukuran Kebahagiaan Berbasis Pendekatan Indigenous Psychology: Studi Multitrait - Multimethod. Jurnal Psikologi, 37(2), 176-188.

Dickens, C. (1859). A Tale of Two Cities. London: Chapman \& Hall.

Lapsley, D. K., \& Stey, P. C. (2011). Id, Ego, and Supereego. Encyclopedia of Human Behavior, 1-9.

Navaneedhan, C. G. (2012). Balance of Internal Drive , Ego and Super Ego through Self-Hypnosis. Journal of
Behavioral and Brain Science, 2012(May), 221-224. https://doi.org/10.4236/jbbs.2012.2 2025

Rennison, N. (2001). The Pocket

Essential FREUD \&

PSYCHOANALYSIS. (Nick

Rennison, Ed.). USA: Trafalgar

Square Publishing.

Shneidman, E. S. (2004). Autopsy of a Suicidal Mind (1st ed.). New York: Oxford University Press.

Wibowo, I. S. W. (2013). Semiotika Komunikasi - aplikasi prakttis bagi penelitian dan skripsi komunikasi (2nd ed.). Jakarta: Mitra Wacana Media. 